\title{
Konsep Diri Dan Kecerdasan Emosional Terhadap Perilaku Prososial Remaja Sekolah Menengah Atas
}

\author{
Ayu Ratna Tri Utari dan I Made Rustika \\ Universitas Udayana
}

\begin{abstract}
Prosocial behaviour is the form of behaviour that benefit others in the sense of material, physical and psychological, which is done on its own initiative without any specific motives. Prosocial behaviour is important for adolescents because of the need to be accepted by their social environment. The purpose of the study was to gather information regarding the role of self concept and emotional intelligence towards prosocial behaviour of adolescents. The subjects in this research is adolescents which currently are studying in senior high school in Denpasar. The sample consists of 107 people. The results of multiple regression test shows that self concept and emotional intelligence has a role towards prosocial behaviour of adolescents by $37,7 \%$ with significance of $0,000(p<0,05)$.
\end{abstract}

Keywords: Prosocial Behaviour; Self Concept; Emotional Intelligence; Adolescent.

\begin{abstract}
Abstrak
Perilaku prososial merupakan suatu bentuk perilaku yang memberikan keuntungan bagi orang lain baik dari segi materi, fisik, dan psikologis, yang dilakukan berdasarkan inisiatif sendiri tanpa adanya motif tertentu. Perilaku prososial penting untuk dimiliki remaja karena adanya kebutuhan untuk dapat diterima oleh lingkungan sosialnya. Penelitian ini bertujuan untuk mengetahui peran konsep diri dan kecerdasan emosional terhadap perilaku prososial pada remaja di Denpasar. Subjek penelitian merupakan remaja yang sedang menempuh pendidikan Sekolah Menengah Atas di Denpasar yang berjumlah 107 orang. Hasil uji regresi berganda menunjukkan adanya peran konsep diri dan kecerdasan emosional terhadap perilaku prososial sebesar 37,3\% dengan signifikansi 0,000 ( $p<0,05)$.
\end{abstract}

Kata kunci: Perilaku Prososial; Konsep Diri; Kecerdasan Emosional; Remaja.

Manusia merupakan makhluk sosial yang tidak dapat hidup sendiri dan memerlukan orang lain untuk saling berinteraksi dalam kehidupannya. Dalam melakukan interaksi, manusia biasanya menunjukkan kepedulian berupa perilaku menolong yang merupakan salah satu bentuk perilaku prososial. Saat remaja, individu dituntut agar dapat melakukan penyesuaian dengan kepercayaan, nilai dan norma yang ada dalam lingkungannya, sehingga dapat menunjukkan perilaku seperti yang diharapkan oleh lingkungan sosialnya. 
Saat berada pada masa remaja, individu dihadapkan dengan berbagai perubahan, seperti perubahan kognitif, sosio-emosional, dan tentu saja biologis. Remaja mengalami peningkatan pola pikir idealistis, abstrak, dan logis, serta remaja berusaha beradaptasi dengan perubahan fisik, biologis, dan sosial. Tidak hanya mengalami berbagai perubahan, remaja juga berkaitan dengan pencarian identitas serta cara membangun hubungan dengan orang lain. Menurut Monks dan Harditono (1999), masa remaja dibagi menjadi tiga tahapan yaitu remaja awal dengan rentang usia 12-15 tahun, remaja pertengahan dengan rentang usia 15-18 tahun, dan remaja akhir dengan rentang usia 18-21 tahun.

Masa remaja pertengahan kurang lebih berada pada jenjang sekolah menengah atas, dimana remaja pertengahan biasanya meluangkan lebih banyak waktu bersama dengan teman sebaya. Keberadaan teman sebaya merupakan hal yang sangat berarti bagi remaja dan remaja juga sangat rentan mengalami kebingungan (Monks \& Harditono, 1999). Oleh karena itu, remaja akan berusaha membuat diri diterima di lingkungan sosial dan mendapatkan dukungan (Hurlock, 1980).

Pada tahap ini, remaja mulai menunjukkan perilaku tolong-menolong atau biasa disebut perilaku prososial karena remaja menjadi lebih rasional dan mampu menggunakan kematangan kognitifnya (Eisenberg \& Fabes, 1998). Perilaku prososial biasa dikenal sebagai perilaku menolong, meskipun dalam perilaku prososial tidak hanya berupa tindakan menolong. Myers (dalam Sarwono, 2002) menyatakan bahwa perilaku prososial ialah tingkah laku positif yang dilakukan atas dasar sukarela tanpa mengharapkan adanya imbalan dari orang lain, serta dapat memberikan keuntungan atau membuat kondisi psikis dan fisik orang lain menjadi lebih baik. Perilaku prososial berasal dari dalam diri individu dan ditunjukan dalam bentuk perilaku seperti murah hati, persahabatan, kerja sama, menolong dan juga penyelamatan.

Perilaku prososial ini penting bagi remaja. Remaja yang memiliki perilaku prososial yang tinggi akan semakin mudah mendapatkan penerimaan lingkungan sekitar, tak terkecuali penerimaan dari teman sebayanya (Greener, 2000). Perilaku prososial sangat bermanfaat bagi interaksi sosial remaja dan mencegah timbulnya perilaku antisosial seperti merokok, minumminuman keras, perkelahian antar pelajar, penggunaan obat-obat terlarang dan perilaku yang 
mengarah pada tindak kriminal, bahkan bullying. Sebaliknya, remaja yang memiliki perilaku prososial yang rendah akan menimbulkan adanya ketidakpedulian terhadap lingkungan sekitarnya.

Akan tetapi, seiring berjalannya waktu dan perkembangan teknologi, remaja menjadi kurang bersosialisasi dengan lingkungan sekitar dan sikap sosial yang dimiliki pun berkurang dimana remaja dikatakan cenderung melakukan sesuatu berdasarkan atas kepentingan pribadinya (Sarwono, 2012). Remaja cenderung hanya memikirkan dirinya sendiri dan menjalani gaya hidup hedonis tanpa mengembangkan empati (Gunarsa, 2004). Lestari (2013) juga mengungkapkan bahwa perilaku prososial dalam kehidupan sehari-hari berupa perilaku tolong menolong, solidaritas sosial, kesejahteraan, serta kepedulian individu terhadap orang lain semakin luntur.

Hasil studi pendahuluan pada 20 siswa Sekolah Menengah Atas (SMA) di Denpasar menunjukkan bahwa 6 siswa memiliki perilaku prososial pada tingkat yang sangat tinggi, 9 siswa memiliki perilaku prososial pada tingkat tinggi, 1 siswa memiliki perilaku prososial pada tingkat sedang, dan 4 siswa memiliki perilaku prososial pada tingkat yang rendah. Hal tersebut menunjukkan bahwa tidak semua remaja memiliki taraf perilaku prososial yang tinggi. Taraf perilaku prososial yang berbeda dari setiap individu, menimbulkan pertanyaan bagi peneliti mengapa terdapat remaja SMA yang memiliki taraf perilaku prososial yang rendah, sedangkan yang lainnya memiliki taraf perilaku prososial yang tinggi.

Perkembangan perilaku prososial pada remaja sangat ditentukan oleh pandangan seseorang terhadap dirinya. Pandangan seseorang terhadap diri sering disebut sebagai konsep diri. Konsep diri adalah evaluasi individu tentang diri sendiri, penilaian maupun penaksiran mengenai diri oleh individu yang bersangkutan (Chaplin, 2011). Menurut Fitts (dalam Agustiani, 2009), konsep diri bertindak sebagai kerangka acuan tingkah laku individu dalam berinteraksi dengan lingkungannya.

Individu yang memiliki konsep diri positif mampu untuk menunjukkan perilaku positif dan melakukan kontrol terhadap perilakunya dalam lingkungan dan begitu juga sebaliknya. Konsep diri positif menunjukkan adanya penerimaan diri dimana individu dapat mengenal diri dengan baik. Remaja yang memiliki konsep diri positif mampu untuk menerima kritik, 
memiliki keyakinan terhadap kemampuannya sendiri, mampu untuk mengatasi setiap permasalahan yang dihadapi, memiliki perasaan bahwa dirinya setara dengan orang lain, serta sensitif dengan kebutuhan orang lain yang ada di sekitarnya. Sebaliknya, konsep diri yang negatif meliputi pandangan diri yang tidak teratur atau pandangan diri yang terlalu teratur. Remaja yang memiliki konsep diri negatif akan merasa bahwa dirinya inferior, sangat peka terhadap kritik yang diberikan oleh orang lain, sulit dalam mengakui kelemahan yang dimiliki dan kegagalan yang dialami, responsif dengan pujian yang diberikan untuk dirinya, serta pesimis terhadap kompetisi (Calhoun \& Acocella, 1990; Habibah \& Kurniawan, 2015).

Remaja dengan konsep diri yang positif akan mampu memahami keadaan diri sendiri serta menghayati nilai moral yang ada dalam masyarakat. Adanya pemahaman diri sendiri dan penghayatan terhadap nilai moral yang ada di masyarakat, membuat individu lebih mudah dalam membangun kepekaannya terhadap orang lain serta cenderung memiliki perilaku prososial terhadap lingkungan sosialnya (Habibah \& Kurniawan, 2015). Hasil penelitian (Darmawan, 2015) menunjukkan terdapat hubungan positif antara konsep diri dan perilaku prososial. Remaja dengan konsep diri yang positif akan mampu menunjukkan perilaku prososial dengan baik karena remaja mampu mengenali diri dengan baik sehingga dapat dengan mudah untuk melakukan hubungan dengan orang lain yang ada di sekitarnya, dan dapat meningkatkan pengetahuan tentang dirinya (Darmawan, 2015).

Menurut Baron (dalam Sarwono, 2009), emosi memiliki pengaruh terhadap kecenderungan individu dalam memberikan pertolongan, dimana emosi positif cenderung meningkatkan minat seseorang dalam memberikan pertolongan. Kemampuan individu dalam mengenali, memantau, memahami, dan mengendalikan emosi dalam diri maupun orang lain, serta menggunakan emosi untuk memandu tindakan disebut sebagai kecerdasan emosioanal (Goleman, 2006). Apabila kecerdasan emosional yang dimiliki individu tinggi, maka individu akan mampu untuk memiliki kepekaan terhadap situasi atau perasaan yang sedang dialami oleh orang lain, sehingga dirinya dapat memposisikan diri menjadi orang lain yang sedang membutuhkan pertolongan tersebut, sehingga akan memunculkan perilaku prososial. Remaja yang memiliki kecerdasan emosional yang tinggi mampu untuk menunjukkan perilaku prososial yang baik (Husada, 2013). 
Perilaku prososial remaja juga sangat dipengaruhi oleh kemampuan merasakan perasaan orang lain (empati) yang merupakan salah satu aspek dari kecerdasan emosional. Empati bukan hanya sebagai reaksi yang bersifat emosi, namun juga merupakan keterampilan kognitif seperti halnya kemampuan untuk mengenali kondisi emosi orang lain dan kemampuan dalam mengambil peran. Robert dan Strayer (dalam Asih \& Pratiwi, 2010) mengungkapkan bahwa empati berpengaruh terhadap perilaku prososial, dimana empati berkaitan dengan kemampuan individu dalam mengekspresikan emosi dan pengambilan peran. Empati menjadi batasan dari seseorang untuk menentukan apakah dirinya akan melakukan atau mengaktualisasikan gagasan prososial yang dimiliki ke dalam perilaku atau tidak. Aspek keterampilan sosial dari kecerdasan emosional juga terkait dengan perilaku prososial remaja karena dapat mendukung keberhasilan individu dalam pergaulan, membantu individu dalam menjalin hubungan dengan orang lain, dapat menggerakan dan mengilhami orang lain, membantu dalam membina hubungan, meyakinkan dan memengaruhi, serta dapat membuat orang lain merasa nyaman (Goleman, 2000).

Melihat adanya peran antara konsep diri dan kecerdasan emosional terhadap perilaku prososial remaja, maka penelitian ini dilakukan untuk mengetahui “Peran Konsep Diri Dan Kecerdasan Emosional Terhadap Perilaku Prososial Remaja Sekolah Menengah Atas di Denpasar".

\section{Metode}

Studi ini berupa penelitian kuantitatif non-eksperimen yang terdiri dari satu variabel terikat dan dua variabel bebas. Varibel terikat penelitian ialah perilaku prososial dan variabel bebas penelitian terdiri dari konsep diri dan kecerdasan emosional. Populasi yang digunakan pada penelitian ialah remaja yang merupakan siswa atau siswi Sekolah Menengah Atas yang ada di Denpasar. Subjek penelitian ini sebanyak 107 siswa SMA di Denpasar. Pemilihan sampel menggunakan teknik multi stage cluster sampling dengan mengundi daerah yang ada di Denpasar berdasarkan Kecamatan, kemudian peneliti mengundi Sekolah Menengah Atas yang terletak di Kecamatan yang terpilih, selanjutnya peneliti akan mengundi kelas untuk dijadikan sampling individu. 
Pengambilan data penelitian menggunakan alat ukur berupa skala Likert yang terdiri atas skala perilaku prososial yang disusun peneliti sesuai aspek perilaku prososial yang dikemukakan oleh Mussen, Conger, dan Kagan (1989), skala konsep diri yang disusun peneliti berdasarkan dimensi konsep diri yang dikemukakan oleh Fitts (dalam Agustiani, 2009), dan skala kecerdasan emosional dalam penelitian ini menggunakan modifikasi skala yang disusun oleh Rustika (2014) dengan menggunakan aspek kecerdasan emosional yang dikemukakan oleh Goleman (2000). Analisis data penelitian menggunakan dua uji yaitu uji asumsi penelitian dan uji hipotesis penelitian. Uji asumsi penelitian terdiri dari uji normalitas dengan KolmogorovSmirnov, uji linearitas dengan Compare Mean, dan uji multikolinearitas. Uji hipotesis menggunakan regresi berganda.

Sebelum skala disebar kepada sampel penelitian, peneliti melakukan uji coba alat ukur kepada 70 siswa yang berusia 15 sampai 18 tahun dan menempuh pendidikan di kelas $\mathrm{X}$ pada Sekolah Menengah Atas Negeri 3 Denpasar. Kemudian peneliti melakukan analisis validitas dan reliabilitas skala. Hasil validitas aitem-aitem valid pada skala konsep diri berkisar antara 0,253 sampai 0,662, skala konsep diri sekitar 0,254 sampai 0,665, dan skala kecerdasan emosional berkisar antara 0,281 sampai 0,712. Hasil uji reliabilitas masing-masing skala dengan menggunakan teknik Alpha Cronbach yaitu skala perilaku prososial sebesar 0,883, skala konsep diri senilai 0,907 dan skala kecerdasan emosional sebesar 0,874.

\section{H a s i 1}

Berikut adalah data demografi yang ditemukan:

Tabel 1

Deskripsi subjek penelitian

\begin{tabular}{llll}
\hline Variabel & Kategori & Frekuensi & Persentase \\
\hline Jenis Kelamin & Laki-laki & 47 & $43,9 \%$ \\
& Perempuan & 60 & $56,1 \%$ \\
Usia & 15 tahun & 2 & $1,9 \%$ \\
& 16 tahun & 57 & $53,3 \%$ \\
& 17 tahun & 43 & $40,2 \%$ \\
& 18 tahun & 5 & $4,6 \%$ \\
\hline
\end{tabular}

Keterangan: $\mathrm{N}=107$ orang

Berdasarkan deskripsi subjek penelitian, diketahui bahwa mayoritas subjek yang berpartisipasi dalam penelitian ini adalah perempuan sebanyak 60 orang atau sebesar 56,1\%, 
dan 47 orang subjek berjenis kelamin laki-laki sebesar 43,9\%. Berdasarkan usia subjek penelitian, sebagian besar subjek penelitian berusia 16 tahun yaitu sebanyak 57 orang (53,3\%), 17 tahun sebanyak 43 orang (40,2\%), 18 tahun sebanyak 5 orang $(4,6 \%)$, dan 15 tahun sebanyak 2 orang $(1,9 \%)$.

Tabel 2 menjelaskan tentang deskripsi statistik data penelitian yang dihitung dengan membandingkan rerata empiris dengan rerata teoretis untuk melihat kategori secara umum pada masing-masing variabel.

Tabel 2

Deskripsi statistik data penelitian berdasarkan variabel penelitian

\begin{tabular}{llllll}
\hline Variabel & Rerata Teoritis & Rerata Empiris & SD Teoritis & SD Empiris & $\mathrm{t}$ \\
\hline Konsep Diri & 107,5 & 132,05 & 21,5 & 14,920 & $\begin{array}{l}17,019 \\
(\mathrm{p}=0,000)\end{array}$ \\
Kecerdasan Emosional & 85 & 96,75 & 17 & 10,221 & $\begin{array}{l}11,889 \\
(\mathrm{p}=0,000) \\
16,190 \\
(\mathrm{p}=0,000)\end{array}$ \\
Perilaku Prososial & 90 & 110,07 & 18 & 12,826 & \\
\hline
\end{tabular}

Keterangan: $\mathrm{N}=107$ orang

Berdasarkan tabel 2, dapat dilihat bahwa konsep diri memiliki perbedaan mean empiris dan mean teoritis variabel konsep diri sebesar 24,55, dengan nilai t sebesar 17,019 ( $p=0,000)$, variabel kecerdasan emosional memiliki perbedaan mean empiris dan mean teoritis sebesar 11,75, dengan nilai $\mathrm{t}$ sebesar 11,889 ( $\mathrm{p}=0,000)$, dan variabel perilaku prososial memiliki perbedaan mean empiris dan mean teoritis sebesar 20,07, dengan nilai $t$ sebesar 16,190 $(p=0,000)$. Hal ini menunjukkan bahwa ketiga variabel memiliki perbedaan yang signifikan antara mean empiris dan mean teoritis.

Tabel 3 menjelaskan tentang gambaran umum kategorisasi konsep diri, kecerdasan emosional, dan perilaku prososial siswa SMA di Denpasar.

Tabel 3

Kategorisasi subjek penelitian

\begin{tabular}{llllll}
\hline \multirow{2}{*}{ Variabel } & \multicolumn{4}{l}{ Kategorisasi (dalam Persen) } \\
\cline { 2 - 6 } & Sangat Rendah & Rendah & Sedang & Tinggi & Sangat Tinggi \\
\hline Konsep Diri & $0 \%$ & $0,9 \%$ & $18,7 \%$ & $48,6 \%$ & $31,8 \%$ \\
Kecerdasan Emosional & $0 \%$ & $0,9 \%$ & $33,7 \%$ & $55,1 \%$ & $9,3 \%$ \\
Perilaku Prososial & $0 \%$ & $0 \%$ & $21,5 \%$ & $50,5 \%$ & $28 \%$ \\
\hline
\end{tabular}

Keterangan: $\mathrm{N}=107$ orang 
Tabel 3 menunjukkan bahwa sebagian besar subjek mempunyai taraf konsep diri tinggi yaitu sebesar 48,6\%, sebagian besar subjek memiliki taraf kecerdasan emosional tinggi sebesar $55,1 \%$, dan mayoritas subjek memiliki taraf perilaku prososial tinggi yaitu sebesar 50,5\%.

Tabel 4

Hasil uji normalitas data penelitian

\begin{tabular}{llll}
\hline Variabel & Kolmogorv-Smirnov (K-S) & Sig. & Kesimpulan \\
\hline Konsep Diri & 0,074 & 0,184 & Data Normal \\
Kecerdasan Emosional & 0,073 & 0,195 & Data Normal \\
Perilaku Prososial & 0,062 & 0,200 & Data Normal \\
\hline
\end{tabular}

Uji normalitas dilakukan dengan menggunakan teknik Kolmogorov-Smirnov (K-S). Menurut Azwar (2015), data disebut berdistribusi normal apabila signifikansi K-S lebih besar dari 0,05 ( $\mathrm{p}>0,05)$. Berdasarkan hasil uji normalitas pada tabel 4 menunjukkan nilai KolmogorovSmirnov konsep diri sebesar 0,074 dan signifikansi 0,184 ( $>>0,05)$, variabel kecerdasan emosional memiliki nilai K-S sebesar 0,073 dan signifikansi 0,195 ( $p>0,05)$ dan variabel perilaku sosial menunjukkan nilai K-S sebesar 0,062 dan signifikansi 0,200 ( $>>0,05)$. Artinya, seluruh data variabel terdistribusi secara normal.

Tabel 5

Hasil uji linearitas data penelitian

\begin{tabular}{llll}
\hline Variabel & Linearity & Deviation from Linearity & Kesimpulan \\
\hline Perilaku Prososial*Konsep Diri & 0,000 & 0,991 & Data Linear \\
Perilaku Prososial*Kecerdasan Emosional & 0,000 & 0,122 & Data Linear \\
\hline
\end{tabular}

Penelitian ini menggunakan compare means sebagai uji linearitas. Tabel 5 menunjukkan bahwa terdapat hubungan yang linear antara variabel perilaku prososial dan konsep diri dengan signifikansi linearity sebesar 0,000 $(\mathrm{p}<0,05)$ dan signifikansi deviation from linearity sebesar 0,991 ( $>>0,05)$. Begitu pula hubungan antara perilaku prososial dengan kecerdasan emosional linear dengan signifikansi linearity sebesar $0,000(\mathrm{p}<0,05)$ dan signifikansi deviation from linearity sebesar 0,122 ( $>0,05)$. Dengan demikian, dapat disimpulkan bahwa terdapat hubungan linear antara perilaku prososial dengan konsep diri serta perilaku prososial dengan kecerdasan emosional. 
Tabel 6

Hasil uji multikolinearitas data penelitian

\begin{tabular}{llll}
\hline & \multicolumn{3}{c}{ Variance Inflation Factor } \\
Variabel & Tolerance & $($ VIF) & Kesimpulan \\
\hline Konsep Diri & 0,394 & 2,537 & Tidak terjadi multikolinearitas \\
Kecerdasan Emosional & 0,394 & 2,537 & Tidak terjadi multikolinearitas \\
\hline
\end{tabular}

Pengambilan keputusan apakah prediktor memiliki gejala multikolinearitas atau tidak, dapat dilihat pada nilai tolerance $>0,1$ dan nilai VIF $<10$ (Ghozali, 2005). Berdasarkan tabel 6 dapat dilihat bahwa variabel konsep diri dan kecerdasan emosional memiliki tolerance $>0,1$ dan nilai VIF < 10, sehingga dapat disimpulkan bahwa tidak terjadi multikolinearitas antar variabel.

Uji hipotesis dalam penelitian ini yaitu menggunakan model regresi berganda. Hasil analisis dapat dilihat di tabel 7.

Tabel 7

Hasil uji regresi berganda

\begin{tabular}{llllll}
\hline Model & Sum of Squares & Df & Mean Square & F & Sig. \\
\hline Regression & 6512,716 & 2 & 3256,358 & 31,000 & 0,000 \\
Residual & 10924,686 & 104 & 105,045 & & \\
Total & 17437,402 & 106 & & & \\
\hline
\end{tabular}

Berdasarkan hasil uji regresi berganda pada tabel 7 menunjukkan F hitung sebesar 31,000 dan signifikansi sebesar 0,000 $(p<0,05)$. Dengan demikian, model regresi dalam penelitian ini dapat digunakan untuk memprediksi perilaku prososial. Kesimpulan yang didapatkan adalah bahwa konsep diri dan kecerdasan emosional secara bersama-sama berperan terhadap perilaku prososial remaja Sekolah Menengah Atas di Denpasar. Besar pengaruh dari kedua variabel dalam penelitian ini dapat dilihat pada tabel 8 .

Tabel 8

Besar sumbangan variabel bebas terhadap variabel terikat

\begin{tabular}{llll}
\hline $\mathrm{R}$ & $R$ Square & Adjusted $R$ Square & Std. Error of the Estimate \\
\hline 0,611 & 0,373 & 0,361 & 10,249 \\
\hline
\end{tabular}

Berdasarkan hasil pada tabel 8 menunjukkan bahwa nilai $\mathrm{R}$ sebesar 0,611 dengan nilai koefisien determinasi ( $R$ Square) sebesar 0,373. Hal tersebut mengindikasikan konsep diri dan kecerdasan emosional secara bersama-sama menentukan 37,3\% taraf perilaku prososial, 
sedangkan 62,7\% ditentukan oleh variabel lain yang tidak diteliti. Dari hasil uji regresi berganda juga diperoleh hasil uji hipotesis minor untuk menganalisis peran konsep diri dan kecerdasan emosional terhadap perilaku prososial secara terpisah. Hasil uji dapat dilihat pada tabel 9 .

Tabel 9

Hasil Uji Regresi Berganda Nilai Koefisien Beta dan Nilai t Variabel Konsep Diri dan Kecerdasan Emosional terhadap Perilaku Prososial

\begin{tabular}{lccccc}
\hline \multirow{2}{*}{ Variabel } & \multicolumn{2}{c}{ Unstandardized Coefficients } & Standardized Coefficients & \multirow{2}{*}{ T } & Sig. \\
\cline { 2 - 3 } & $\mathrm{B}$ & Sts. Error & Beta & & \\
\hline (Constant) & 33,804 & 9,762 & 0,303 & 3,463 & 0,001 \\
Konsep Diri & 0,261 & 0,106 & 0,345 & 2,453 & 0,016 \\
Kecerdasan Emosional & 0,433 & 0,155 & 2,789 & 0,006 \\
\hline
\end{tabular}

Tabel 9 menunjukkan konsep diri mempunyai nilai koefisien beta terstandarisasi sebesar 0,303, nilai t sebesar 2,453, dan signifikansi 0,016 ( $p<0,05)$, artinya konsep diri berperan secara signifikan terhadap perilaku prososial. Koefisien beta terstandarisasi variabel kecerdasan emosional bernilai 0,345 dengan nilai t sebesar 2,789, dan signifikansi 0,006 ( $\mathrm{p}<0,05)$. Hal ini mengindikasikan kecerdasan emosional berperan secara signifikan terhadap perilaku prososial. Tabel 9 juga mengindikasikan bahwa peran kecerdasan emosional pada perilaku prososial lebih besar dibandingkan peran konsep diri pada perilaku prososial. Ini ditunjukkan oleh besaran nilai koefisien beta terstandarisasi kecerdasan emosional lebih tinggi daripada konsep diri.

Berdasarkan hasil uji hipotesis, dapat ditulis persamaan garis regresi berganda sebagai berikut:

$$
\mathrm{Y}=33,804+0,261 \mathrm{X} 1+0,433 \mathrm{X} 2
$$

Keterangan:

$\mathrm{Y} \quad=$ Perilaku Prososial

$\mathrm{X}_{1} \quad=$ Konsep Diri

$\mathrm{X}_{2} \quad=$ Kecerdasan Emosional

Rumus diatas dapat dijelaskan sebagai berikut:

a. Konstanta sebesar 33,804 menyatakan bahwa jika tidak ada penambahan atau peningkatan skor pada konsep diri ataupun kecerdasan emosional maka taraf perilaku prososial sebesar 33,804 . 
b. Koefisien regresi $\mathrm{X} 1$ sebesar 0,261 menyatakan bahwa setiap penambahan atau peningkatan satuan skor subjek pada variabel konsep diri, maka akan terjadi peningkatan taraf perilaku prososial sebesar 0,261

c. Koefisien regresi X2 sebesar 0,433 menyatakan bahwa setiap penambahan atau peningkatan satuan skor subjek pada variabel kecerdasan emosional, maka akan terjadi peningkatan taraf perilaku prososial sebesar 0,433 .

Tabel 10

Hasil uji hipotesis penelitian

Hipotesis

Hasil

Hipotesis Mayor:

Konsep Diri dan Kecerdasan Emosional berperan Meningkatkan Perilaku Prososial Remaja Diterima Sekolah Menengah Atas di Denpasar.

Hipotesis Minor:

a. Konsep Diri berperan Meningkatkan Perilaku Prososial Remaja Sekolah Menengah Atas Diterima di Denpasar.

b. Kecerdasan Emosional berperan Meningkatkan Perilaku Prososial Remaja Sekolah Diterima Menengah Atas di Denpasar.

\section{Pembahasan}

Remaja di Sekolah Menengah Atas di Denpasar mampu mengembangkan perilaku prososial karena terdapat peran yang signifikan dari konsep diri dan kecerdasan emosional, sehingga hipotesis mayor pada penelitian ini dapat diterima. Peran konsep diri dan kecerdasan emosional yang menentukan peilaku prososial sebesar 37,3\% dan sebesar 62,7\% ditentukan oleh variabel lain yang tidak diteliti. Hasil lainnya mengindikasikan konsep diri berperan signifikan secara mandiri pada perilaku prososial remaja Sekolah Menengah Atas di Denpasar. Konsep diri merupakan suatu aspek penting yang terdapat dalam diri seseorang yang menjadi kerangka acuan untuk berinteraksi dengan lingkungannya, dengan kata lain konsep diri mampu untuk menuntun individu dalam berperilaku (positif atau negatif) sesuai dengan pandangan yang dimiliki terhadap dirinya (Fitts dalam Agustiani, 2009).

Individu yang memiliki konsep diri positif akan lebih peka terhadap kebutuhan orang lain. Perasaan peka tersebut berkaitan dengan empati dasar dan ketepatan empatik, yaitu kemampuan dalam membaca isyarat verbal dan nonverbal yang diberikan oleh orang lain (Goleman, 2007). Individu yang dapat menggunakan empatinya dengan tepat akan mampu 
merasakan pikiran dan perasaan orang lain yang dapat berdampak terhadap perilaku prososial. Hal ini sejalan dengan pernyataan Habibah dan Kurniawan (2015) yang menyatakan bahwa remaja dengan konsep diri positif akan mampu memahami keadaan dirinya serta menghayati nilai moral yang ada dalam masyarakat. Adanya pemahaman diri sendiri dan penghayatan terhadap nilai moral membuat individu lebih mudah dalam membangun kepekaan terhadap lingkungan sosialnya.

Konsep diri yang positif akan membuat seseorang memiliki perasaan berharga terhadap dirinya, berkompetensi, dan percaya diri (Burns, 1993). Melalui hal tersebut, individu akan mampu menyampaikan sesuatu dengan ekspresi yang tepat, merasa percaya diri dalam berbagai situasi sosial, dan mampu mengenali dirinya dengan baik. Hal tersebut sejalan dengan hasil penelitian Darmawan (2015) yang menyatakan bahwa konsep diri memiliki hubungan dengan perilaku prososial. Remaja dengan konsep diri yang positif akan mampu mengenali dirinya dengan baik sehingga dapat dengan mudah melakukan hubungan dengan orang lain yang ada di sekitarnya, dan dapat meningkatkan pengetahuan tentang dirinya.

Faktor lain yang berhubungan dengan perilaku prososial remaja di Kota Denpasar adalah kecerdasan emosional. Pada penelitian ini, kecerdasan emosional berperan secara signifikan terhadap perilaku prososial remaja Sekolah Menengah Atas di Denpasar. Hal tersebut sejalan dengan hasil penelitian Husada (2013) yang menyatakan bahwa remaja yang memiliki kecerdasan emosional yang tinggi lebih mampu untuk menunjukkan perilaku prososialnya dengan baik. Selain itu hasil penelitian Asih dan Pratiwi (2010) juga menyatakan bahwa kecerdasan emosional memengaruhi perilaku prososial. Individu yang memiliki kecerdasan emosional yang tinggi lebih cepat dalam mengenali emosi yang sedang dirasakan, dan dengan segera dapat mengelola emosi tersebut.

Hasil penelitian Forgas (dalam Baron \& Byrne, 2003), menyatakan bahwa kecerdasan emosional yang tinggi akan memengaruhi kemampuan individu dalam mengatur suasana hati. Individu dengan suasana hati yang baik memiliki peluang yang lebih besar untuk menolong orang lain, dimana hal tersebut merupakan salah satu aspek perilaku prososial. Hal tersebut sejalan dengan pernyataan Goleman (2000), yaitu inti dari hubungan sosial yang baik ialah koordinasi dari suasana hati. Individu yang dapat beradaptasi dengan orang lain dan suasana 
hatinya, dapat lebih berempati, memiliki tingkat emosional yang baik, dan akan lebih mudah dalam menyesuaikan diri dengan lingkungan sosialnya.

Taylor, Peplau, dan Sears (2009) menyatakan bahwa salah satu aspek dalam kecerdasan emosional yang berperan terhadap perilaku prososial adalah empati. Individu yang memiliki empati tinggi akan lebih mudah merasa iba dan tersentuh, sehingga dapat merasakan penderitaan orang lain. Hal tersebut sejalan dengan pernyataan Batson (dalam Goleman, 2000) yang menyatakan bahwa terdapat hubungan yang erat antara kecerdasan emosional khususnya empati terhadap perilaku prososial, hal ini berarti individu yang mempunyai empati tinggi cenderung lebih mudah dalam menolong orang lain dan menunjukkan perilaku prososial. Hasil penelitian Sabiq dan Djalali (2012) menunjukkan adanya hubungan antara tingkat kecerdasan emosional dan kecerdasan spiritual pada perilaku prososial secara signifikan, artinya semakin tinggi tingkat kecerdasan emosional dan kecerdasan spiritual akan meningkatkan perilaku prososial.

Hasil penelitian menunjukkan bahwa kecerdasan emosional mempunyai peran yang lebih besar pada perilaku prososial dibandingkan dengan peran konsep diri pada perilaku prososial. Individu dengan kecerdasan emosional yang tinggi akan membentuk suatu kompetensi dalam menyadari emosi yang dimilikinya, sehingga akan lebih mudah mengelola emosi dan mengelola konflik antar personal. Hal tersebut akan berdampak pada kemampuan individu dalam menyelesaikan suatu permasalahan yang dihadapi dengan baik dan memaksimalkan kemampuan dalam penyesuaian diri terhadap lingkungan sosialnya, sehingga dapat meningkatkan perilaku prososial (Bradberry \& Su, 2006). Hasil penelitian Hanana (2018) menyatakan terdapat pengaruh kecerdasan emosional terhadap perilaku prososial, aspek kecerdasan emosional yang berpengaruh terhadap perilaku prososial dalam penelitian ini adalah mengenali emosi diri dan ketrampilan sosial.

Hasil kategorisasi menunjukkan taraf kecerdasan emosional tinggi. Tingginya taraf kecerdasan emosional dapat dipengaruhi oleh beberapa faktor. Menurut Goleman (2009), faktor yang dapat memengaruhi kecerdasan emosional adalah lingkungan keluarga dan lingkungan non keluarga. Dalam perkembangannya, manusia telah mempelajari keterampilan sosial dan emosional sejak bayi, dimana pembelajaran tersebut dapat diperoleh dari lingkungan keluarga. 
Shapiro (1997) menyatakan bahwa peranan lingkungan terutama orangtua, pada masa kanakkanak sangat memengaruhi dalam pembentukan kecerdasan emosional.

Salah satu faktor lingkungan keluarga yang memengaruhi yaitu tingkat pendidikan orangtua. Orangtua yang berpendidikan tinggi akan memiliki wawasan yang lebih luas dan pola pikir yang lebih terbuka. Pendidikan yang baik akan membuat orangtua memiliki pengalaman dan pengetahuan yang lebih luas, sehingga lebih mudah dalam menerima informasi dari luar terutama terkait dengan cara pengasuhan anak yang dapat memengaruhi kecerdasan emosional. Hal ini sejalan dengan penelitian Haryanti (2014) yang menyatakan bahwa pendidikan orangtua yang tinggi berkaitan dengan lancarnya diskusi yang baik antara orangtua dan anak, sehingga anak dapat menumbuhkan empati, mampu bekerja sama, dan matang dalam menentukan keputusan.

Selain pendidikan, pemberian kasih sayang kepada anak juga menjadi faktor penting dalam perkembangan kecerdasan emosional anak. Orangtua terutama ibu yang mempunyai waktu penuh untuk berinteraksi dan menjalin hubungan dengan anak, sehingga berperan dalam pembentukan kecerdasan emosional anak. Penting bagi orangtua menyediakan sumber kasih sayang agar dapat memuaskan kebutuhan anak. Anak yang mendapatkan kasih sayang dari orangtuanya atau pengganti orangtuanya akan memiliki perkembangan emosi yang lebih terjaga sehingga berpeluang untuk lebih cerdas secara emosional (Hurlock, 1980). Berdasarkan hasil penelitian Anggraini dan Emmanuel (2016), kelekatan orangtua dengan anak memberikan pengaruh signifikan terhadap perkembangan emosi anak.

Konsep diri subjek penelitian tergolong tinggi. Tingginya taraf konsep diri remaja Sekolah Menengah Atas di Denpasar dapat dikaitkan dengan proses kegiatan belajar mengajar di sekolah. Berdasarkan hasil studi pendahuluan, diketahui bahwa Sekolah Menengah Atas di Denpasar sudah banyak menerapkan sistem full day school. Proses pembelajaran dengan sistem full day school ini berlangsung secara aktif, kreatif, transformatif, sekaligus intensif (Hasan, 2006). Siswa-siswi dibiasakan untuk melakukan kegiatan seperti mendiskusikan pembelajaran, membentuk kelompok belajar untuk mengerjakan tugas, dan guru melatih dan memotivasi siswa siswinya untuk berani menyampaikan pendapat serta mengajukan pertanyaan. Ketika remaja mendapatkan timbal balik yang positif sata belajar, maka hal ini akan meningkatkan 
konsep diri remaja. Fitss (dalam Agustiani, 2009) menyatakan salah satu faktor penunjang konsep diri adalah pengalaman, terutama pengalaman interpersonal yang dapat memunculkan perasaan positif dan berharga. Kesempatan dan fasilitas yang disediakan sekolah untuk meningkatkan prestasi akademik dan non akademik dapat memberikan motivasi pada siswa yang nantinya akan membentuk konsep diri yang positif pada siswa.

Taraf perilaku prososial terbilang tinggi dan hal ini dapat disebabkan oleh tingginya taraf konsep diri dan kecerdasan emosional subjek penelitian. Hasil analisis data mengindikasikan kedua variabel bebas mempunyai peran pada variabel tergantung. Maka dari itu, taraf kedua variabel bebas yang tinggi berperan pada tingginya taraf variabel tergantung. Perilaku prososial remaja berkembang sesuai dengan proses dari internalisasi terhadap nilai dan norma yang ada dalam lingkungannya (Lam, 2012). Pengembangan perilaku prososial remaja juga sangat dipengaruhi oleh teman sebaya. Ketika berada di lingkungan sekolah remaja akan banyak berinteraksi dengan teman sebaya dan membangun hubungan yang baik. Remaja diterima oleh lingkungan ketika mampu beradaptasi baik dalam dituasi sosial. Remaja juga akan mulai membaca isyarat-isyarat nonverbal yang dapat membantunya belajar merasakan dan memberikan pemahaman atas perasaan orang lain, dan menumbuhkan kepedulian terhadap orang lain.

Seorang siswa akan banyak menghabiskan waktu untuk melakukan kegiatan-kegiatan di sekolah baik yang bersifat akademis maupun non akademis. Salah satu kegiatan non akademis yang mampu mengembangkan perilaku prososial adalah kegiatan ekstrakurikuler. Hal tersebut sejalan dengan penelitian Sauerwein, Theis, dan Fischer (2016) yang menyatakan bahwa ekstrakurikuler memiliki pengaruh terhadap prestasi akademik, kemampuan bekerja sama, dan perilaku prososial. Dalam kegiatan ekstrakurikuler remaja dapat berinteraksi dengan teman sebaya, mengembangkan potensi dan keterampilannya, dan mengembangkan kontrol terhadap dirinya sehingga berperan dalam pengembangan perilaku prososial.

Setelah melakukan prosedur analisis data penelitian, karya tulis ini telah mencapai tujuan penelitian yaitu untuk mengetahui peran konsep diri dan kecerdasan emosional terhadap perilaku prososial remaja Sekolah Menengah Atas di Denpasar, mengetahui peran konsep diri terhadap perilaku prososial remaja Sekolah Menengah Atas di Denpasar, dan mengetahui 
peran kecerdasan emosional terhadap perilaku prososial remaja Sekolah Menengah Atas di Denpasar. Tercapainya tujuan dalam penelitian ini tentunya tidak terlepas dari keterbatasan yang dimiliki peneliti diantaranya belum dilakukan uji analisis lanjutan terhadap usia dan jenis kelamin, sehingga belum diperoleh data empiris yang pasti mengenai variasi penerapan perilaku prososial pada remaja berdasarkan tingkat usia dan jenis kelamin. Selain itu keterbatasan penelitian juga terletak subjek penelitian yang digunakan peneliti, dimana peneliti hanya membatasi remaja Sekolah Menengah Atas di Denpasar, sehingga belum di dapatkan variasi hasil penelitian dengan karakteristik remaja di daerah lainnya.

\section{Kesimpulan}

Berdasarkan penelitian dan analisis data yang telah dilakukan, maka dapat ditarik kesimpulan bahwa konsep diri dan kecerdasan emosional secara bersama-sama berperan meningkatkan perilaku prososial remaja Sekolah Menengah Atas di Denpasar, konsep diri berperan meningkatkan perilaku prososial remaja Sekolah Menengah Atas di Denpasar, dan kecerdasan emosional berperan meningkatkan perilaku prososial remaja Sekolah Menengah Atas di Denpasar. Variabel perilaku sosial, konsep diri, dan kecerdasan emosional pada remaja Sekolah Menengah Atas di Denpasar tergolong tinggi.

\section{Saran}

Bagi remaja disarankan untuk mempertahankan konsep diri tinggi dengan menumbuhkan perasaan diri berharga, percaya diri, serta memberikan penilaian yang objektif pada diri agar tidak terfokus pada penilaian orang lain saja. Remaja diharapkan mampu mempertahankan kecerdasan emosional tinggi dengan mengikuti pelatihan pengelolaan emosi dan mengikuti kegiatan sosial untuk meningkatkan empati. Penelitian ini juga menyarankan bagi orangtua agar mampu memberikan perlakuan pada anak dari sejak dini untuk meningkatkan kecerdasan emosional dengan mengenalkan dasar-dasar emosi, memvalidasi dan merefleksi emosi yang dirasakan, serta meningkatkan konsep diri dengan bersikap bijak terhadap anak dari sejak dini, tidak membanding-bandingkan, dan tetap memberikan penghargaan pada anak. 
Saran bagi peneliti selanjutnya yaitu diharapkan menggunakan subjek penelitian yang lebih besar agar data yang diperoleh dapat lebih representatif dan bervariasi. Peneliti selanjutnya juga diharapkan mampu meneliti variabel bebas lainnya yang mungkin berperan terhadap taraf perilaku prososial dan disarankan agar lebih baik jika menggunakan alat ukur penelitian yang itemnya konsisten untuk meneliti terhadap teman sebaya.

\section{Referensi}

Agustiani, H. (2009). Psikologi perkembangan pendekatan ekologi kaitannya dengan konsep diri dan penyesuaian diri pada remaja. Bandung: Refika Aditama.

Anggraini, H., \& Emmanuel, S. (2016). Hubungan kelekatan dengan kecerdasan emosi pada sosial anak usia dini. Jurnal Pedagogi, 07(02), 18-26.

Asih, G. Y., \& Pratiwi, M. M. S. (2010). Perilaku prososial ditinjau dari empati dan kematangan emosi. Jurnal Psikologi Universitas Muria Kudus, 1(1), 33-42. Retrieved from http://eprints.umk.ac.id/268/1/33_-_42.PDF

Azwar, S. (2015). Penyusunan skala psikologi (2nd ed.). Yogyakarta: Pustaka Belajar.

Baron, R. A., \& Byrne, D. (2003). Psikologi sosial. Jakarta: Erlangga.

Bradberry, T. R., \& Su, L. D. (2006). Ability versus skill based assessment of emotional intelligence. Psicothema, 18(SUPPL.1), 59-66. Retrieved from www.pscothema.com

Burns, R. B. (1993). Konsep diri: Teori, pengukuran, perkembangan, dan perilaku. Jakarta: Arcan.

Calhoun, J. F., \& Acocella, J. R. (1990). Psychology of adjusment human relationship. New York: McGraw-Hill.

Chaplin, J. P. (2011). Kamus lengkap psikologi. (Kartini Kartono, Penerjemah). Jakarta: PT Radja Grafindo Prasada.

Darmawan, C. W. (2015). Hubungan antara konsep diri dengan perilaku prososial siswa SMA Muhammadiyah 1 Malang. Psikovidya, 19(2), 94-105.

Eisenberg, N., \& Fabes, R. A. (1998). Prosocial development. In In W. Damon (Series Ed.) and N. Eisenberg (Vol. Ed.), Handbook of child psychology (vol. 3). Social, emotional, and personality development (5th ed., pp. 701-778). New York: Wiley.

Ghozali, I. (2005). Aplikasi analisis multivariate dengan program SPSS. Jakarta: Gramedia Pustaka Utama.

Goleman, D. (2000). Working with emotional intellegence. Jakarta: Gramedia Pustaka Utama.

Goleman, D. (2006). Emotional intellegence. Jakarta: Gramedia Pustaka Utama.

Goleman, D. (2007). Social intelligence. Jakarta: PT. Gramedia Pustaka Utama.

Goleman, D. (2009). Kecerdasan emosional: Mengapa EI lebih penting daripada IQ. Jakarta: PT. Gramedia Pustaka Utama.

Greener, S. H. (2000). Peer assessment of children's prosocial behaviour. Journal of Moral Education, 29(1), 47-60.

Gunarsa, S. D. (2004). Bunga rampai psikologi perkembangan dari anak sampai usia lanjut. Jakarta: BPK. 
Habibah, N., \& Kurniawan, D. (2015). Konsep diri dan kecenderungan perilaku prososial atas kejadian kecelakaan di jalan raya pada mahasiswa UMSIDA. Jurnal Psikologia, 3(1). Retrieved from http://ojs.umsida.ac.id/index.php/psikologia/article/view/112

Hanana, N. F. (2018). Pengaruh self-esteem dan kecerdasan emosi terhadap perilaku prososial. TAZKIYA Journal of Psychology, 6(1), 85-100.

Haryanti, D. (2014). Hubungan pola asuh orangtua dengan harga diri siswa di SMAN 1 Kretek Bantul. (Skripsi, Program Studi Ilmu Keperawatan Sekolah Tinggi Ilmu Kesehatan 'Aisyiyah Yogyakarta).

Hasan, N. (2006). Fullday school (Model alternatif pembelajaran bahasa asing). Jurnal Tadris Stain Pamekasan, 1(1), 109-118. Retrieved from http://tadris.stainpamekasan.ac.id/index.php/jtd/article/view/105

Hurlock, E. B. (1980). Psikologi perkembangan suatu pendekatan sepanjang rentang kehidupan. (Instiwidayanti dan Soedjarwo, Penerjemah). Jakarta: Erlangga.

Husada, A. K. (2013). Hubungan Pola Asuh Demokratis Dan Kecerdasan Emosi Dengan Perilaku Prososial Pada Remaja. Persona:Jurnal Psikologi Indonesia, 2(3), 266-277. https://doi.org/10.30996/persona.v2i3.160

Lam, C. M. (2012). Prosocial involvement as a positive youth development construct: A conceptual review. The Scientific World Journal. https://doi.org/10.1100/2012/769158

Lestari, R. (2013). Keluarga:tempat proses belajar perilaku prososial. Prosiding seminar nasional parenting methods. Bandung: Alfabeta.

Monks, F. J. K., \& Harditono, S. R. (1999). Psikologi perkembangan pengantar dalam berbagai bagiannya. Yogyakarta: Gadjah Mada University Press.

Mussen, P. H., Conger, J. J., \& Kagan, J. (1989). Child develompment and personality (5th ed.). Harper and Row Publishers.

Rustika, I. M. (2014). Faktor-faktor yang mempengaruhi prestasi akademik pada remaja. (Disertasi Tidak Dipublikasikan, Program Doktor Psikologi Fakultas Psikologi Universitas Gajah Mada).

Sabiq, Z., \& Djalali, M. A. (2012). Kecerderdasan emosi, kecerdasan spiritual dan perilaku prososial santri Pondok Pesantren Nasyrul Ulum Pamekasan. Persona:Jurnal Psikologi Indonesia, 1(2), 53-65. https://doi.org/10.30996/persona.v1i2.21

Sarwono, S. W. (2002). Psikologi sosial, individu, dan teori-teori psikologi sosial. Jakarta: Balai Pustaka.

Sarwono, S. W. (2009). Psikologi remaja. Jakarta: Rajawali Press.

Sarwono, S. W. (2012). Psikologi remaja. Jakarta: Rajawali Press.

Sauerwein, M., Theis, D., \& Fischer, N. (2016). How youths' profiles of extracurricularand leisure activity affect their social development and academic achievement. Journal for Research on Extended Education, 4(1). Retrieved from https:/www.budrichjournals.de/index.php/IJREE/article/view/24778

Shapiro, L. E. (1997). Mengajarkan emotional intelligence pada anak. Jakarta: PT. Gramedia Pustaka Utama.

Taylor, S. E., Peplau, L. A., \& Sears, D. O. (2009). Psikologi sosial. (Tri Wibowo, Penerjemah). Jakarta: Kencana Prenada Media Group. 


\begin{tabular}{|l|l|l|l|l|}
\hline Submit & Review & Revisi & Diterima & Publis \\
\hline $30-07-2020$ & $05-10-2020$ sd 24-11-2020 & $24-11-2020$ & $24-11-2020$ & $27-1-2021$ \\
\hline
\end{tabular}

Ayu Ratna Tri Utari dan I Made Rustika

Universitas Udayana

Email : mangayuratna10@gmail.com, imaderustika@gmail.com 